\title{
A NEW FOSSIL MOTH FROM FLORISSANT.
}

\author{
By T. D. A. Cockerell,
}

University of Colorado, Boulder, Colo.

Many years ago, a fossil insect, supposed at the time to belong to Trichoptera, was found by Mr. Geo. N. Rohwer at Station 14 in the Miocene Shales of Florissant, Colorado. By some oversight, it had not been studied until yesterday, when I took it out to show to some students as an example of a fossil caddis-fly. A little examination revealed unexpected characters, and upon close study it was found that we had no caddis, but a moth. With the higher power of the binocular it was easy to see the scales, which thickly covered the anterior wings. On one side the wings are spread, so that their outline can be clearly seen; but $\mathrm{J}$ cannnt make out the venation of the hind wings, nor that of the anal area of the anterior pair. It is also difficult to see exactly the condition at the apex of the cellula intrusa, but I believe I have drawn it correctly, in which case it presents no unique features. The genus may be definitely referred to the Cossidæ, and the general aspect is not unlike that of species of Zeuzera, Givira or Comadia. The abdomen, which I have drawn thick and short, is evidently lacking the apical part, and it may well have been long as in most existing Cossidæ.

\section{Adelopsyche new genus}

Rather small, thick bodied moths, the anterior wings long, with subparallel margins, broadly rounded at apex, heavily scaled, without spots or bands, but probably finely speckled. Scales fairly broad, suboval or more elongate, apically bidentate. Veins strong, basally stout; $R_{1}$, leaving common stem about as far from radial cell as length of that cell; radial cell small, cuneiform, emitting the quite simple $R_{2}$ and $R_{3}$; from the end of the cell (in the sense of lepidopterists,) and above the median cell or cellula intrusa, arise $R_{4}, R_{5}$ and $M_{1}$, the first two (which are simple to the end) well apart, but $R_{5}$ and $M_{1}$ from a common 
point; median cell short, its lower apical corner emitting $\mathrm{M}_{2}$; $\mathrm{M}_{3}, \mathrm{Cu}_{1_{\mathrm{A}}}$ and $\mathrm{Cu}_{1_{\mathrm{B}}}$ (in sense of Tillyard) coming off as in related genera, $\mathrm{Cu}_{1_{\mathrm{A}}}$ distinctly nearer to $\mathrm{M}_{3}$ than to $\mathrm{Cu}_{1 \mathrm{~B}}$.

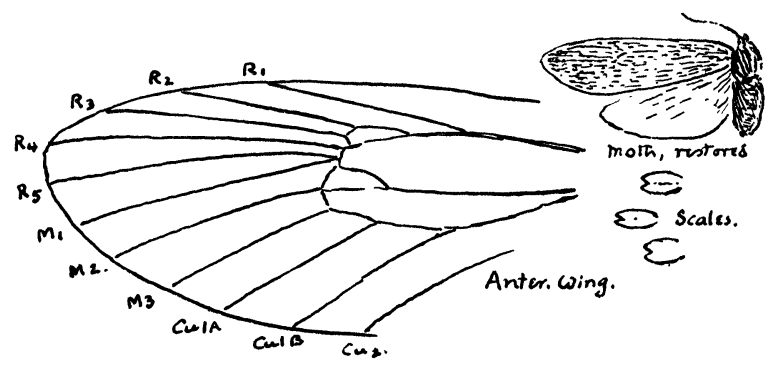

FIG. 1. ADELOPSYCHE FRUSTRANS SP. NOV.

Adelopsyche frustrans new species.

Anterior wing $15 \mathrm{~mm}$. long and 4.5 broad, probably brown or dark gray in life; hind wing about $9.7 \mathrm{~mm}$. long; width of thorax and abdomen, which are dark, nearly $4 \mathrm{~mm}$.; legs not very robust.

In having the veins $R_{2}, R_{3}, R_{4}$ and $R_{5}$ all arising separately, this differs from the American genera (which are well figured by Barnes and McDunnough) and resembles the Australian genus Macrocyttara Turner (Trans. Ent. Soc. London, 1918, p. 169). It differs at once from Macrocyttara in having $\mathrm{R}_{1}$ arising before the radial cell (as in Givira and other genera), and $\mathrm{R}_{4}$ and $\mathrm{R}_{6}$ arising below it. The separate origin of $R_{1}$ is considered by Jefferis Turner to be more primitive than the condition in Macrocyttara. Outside of Macroscyttara, the nearest allies of our fossil are Cossodes (Australia) and Dudgeona (Australia, India, Africa); these however are very distinct. The fossil genus Gurnetia (Cockerell. Ann. Mag. N. Hist. June 1921, p. 472), from the Isle of Wight, agrees in having the branches of the radius separate, while $R_{5}$ and $M_{1}$ come from beneath the radial cell. $\mathrm{Cu}_{1}$ and $\mathrm{Cu}_{2}$ of my figure of Gurnetia are $\mathrm{Cu}_{1_{\mathrm{A}}}$ and $\mathrm{Cu}_{1_{B}}$ of Tillyard. 

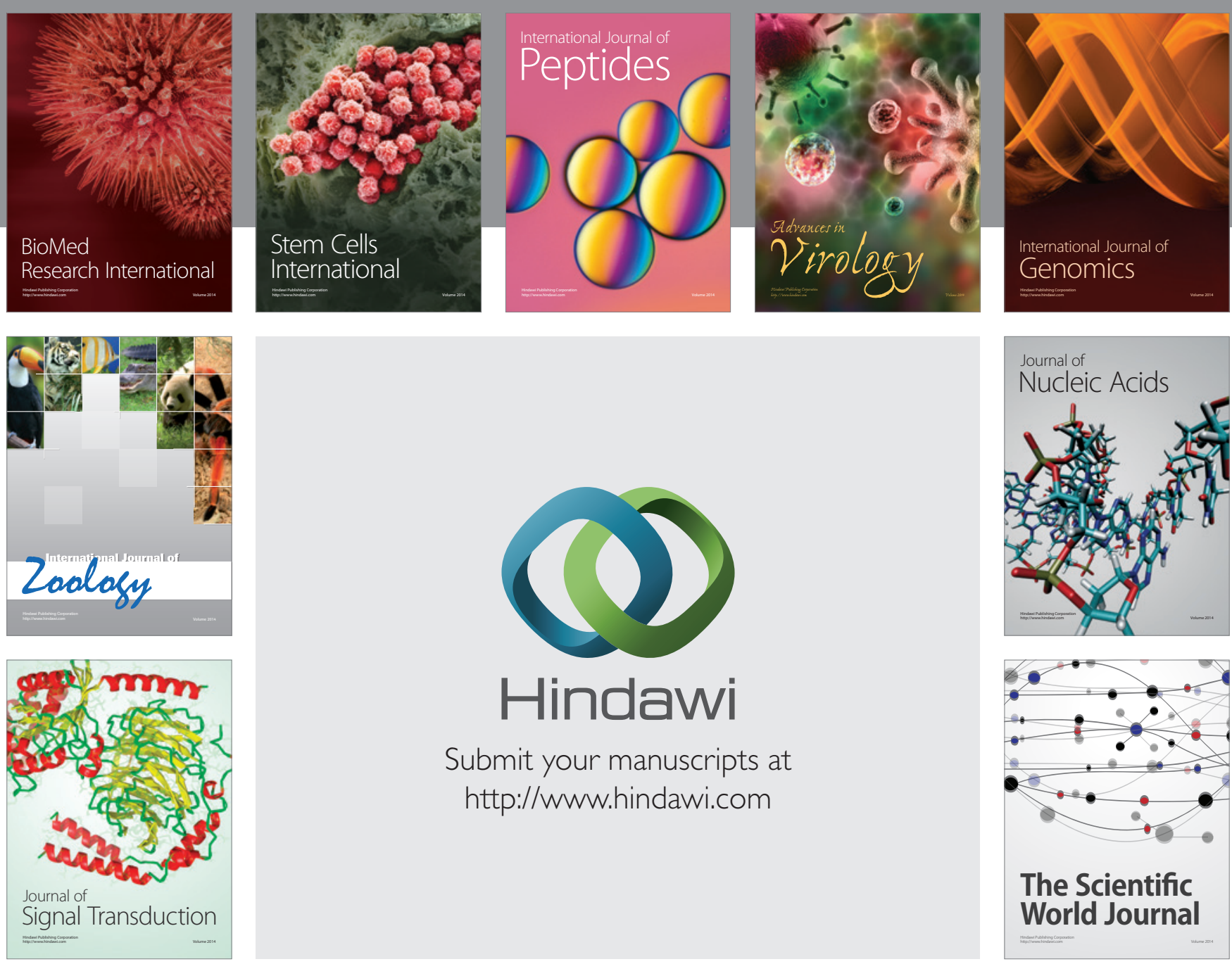

Submit your manuscripts at

http://www.hindawi.com
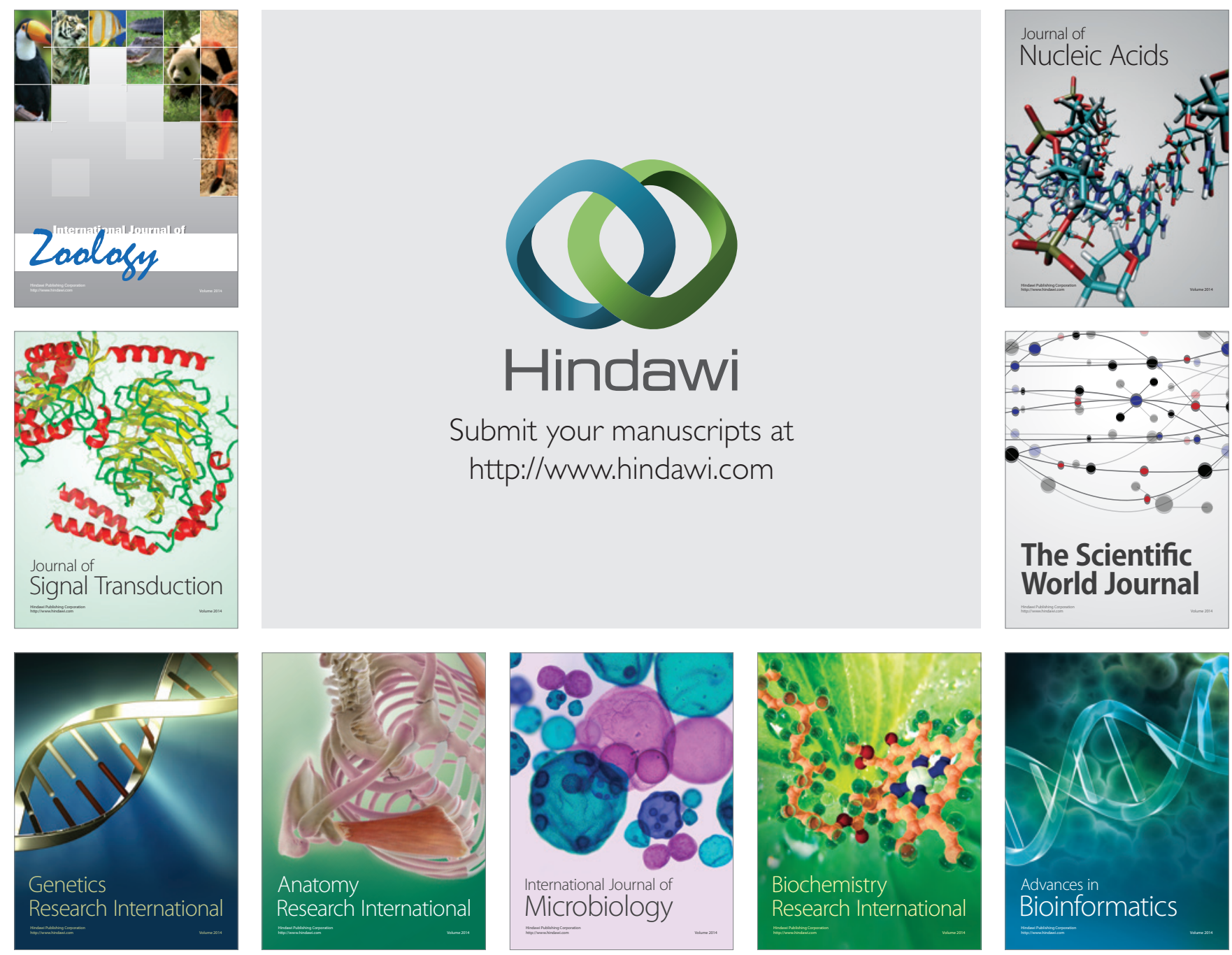

The Scientific World Journal
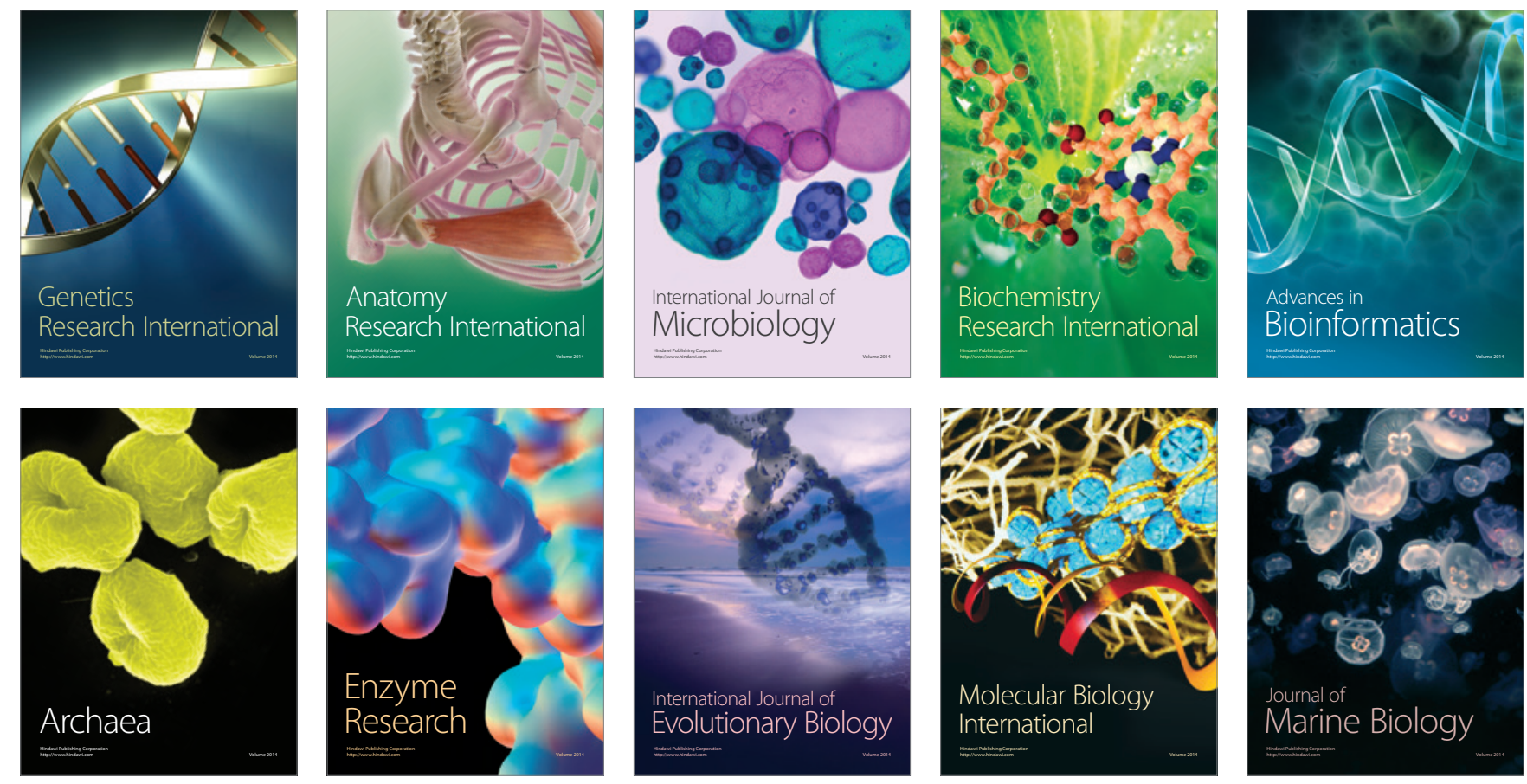